慶應義塾大学学術情報リポジトリ

Keio Associated Repository of Academic resouces

\begin{tabular}{|c|c|}
\hline Title & Effects of 2-mercaptopropionylglycine on the development of X-ray-induced cataract in rats \\
\hline \multicolumn{2}{|l|}{ Sub Title } \\
\hline Author & $\begin{array}{l}\text { 小林，静子(Kobayashi, Shizuko) } \\
\text { 粕谷, 美南子(Kasuya, Minako) } \\
\text { 石井，康雄(Ishii, Yasuo) } \\
\text { 竹鼻, 眞(Takehana, Makoto) } \\
\text { 酒井，一夫(Sakai, Kazuo) } \\
\text { 鈴木, 紀夫(Suzuki, Norio) } \\
\text { 系井，素一(Itoi, Motokazu) }\end{array}$ \\
\hline Publisher & 共立薬科大学 \\
\hline Publication year & 1993 \\
\hline Jtitle & $\begin{array}{l}\text { 共立薬科大学研究年報 (The annual report of the Kyoritsu College of } \\
\text { Pharmacy). No.38 (1993.) , p.78- } 78\end{array}$ \\
\hline \multicolumn{2}{|r|}{ (2) } \\
\hline \multicolumn{2}{|l|}{ Abstract } \\
\hline Notes & 抄録 \\
\hline Genre & Technical Report \\
\hline URL & $\begin{array}{l}\text { https://koara.lib.keio.ac.jp/xoonips/modules/xoonips/detail.php?koara_id=AN00062898-0000003 } \\
\text { 8-0078 }\end{array}$ \\
\hline
\end{tabular}

慶應義塾大学学術情報リポジトリ(KOARA)に掲載されているコンテンツの著作権は、それぞれの著作者、学会または出版社/発行者に帰属し、その権利は著作権法によって 保護されています。引用にあたっては、著作権法を遵守してご利用ください。

The copyrights of content available on the KeiO Associated Repository of Academic resources (KOARA) belong to the respective authors, academic societies, or publishers/issuers, and these rights are protected by the Japanese Copyright Act. When quoting the content, please follow the Japanese copyright act. 


\section{Effect of 2-Mercaptopropionylglycine on the Development of X-ray-induced Cataract in Rats}

Shizuko Kobayashi, Minako Kasuya**, Yasuo Ishin ${ }^{* *}$, Makoto Takehana, Kazuo SAKAI ${ }^{* * *}$, Norio SUzUKI ${ }^{* * *}$ and Motokazu IToI** 小林静子, 粕谷美南子**, 石井康雄 ${ }^{* *}$, 竹鼻 真, 酒井一夫***, 鈴木紀夫***，系井素一**

The effect of 2-mercaptopropionylglycine on the development of cataract induced by a single dose of X-ray (10 Gy) was investigated in rats. Intraperitoneal injection of $20 \mathrm{mg} /$ $\mathrm{kg}$, three times weekly starting 1 day after irradiation delayed the development of $\mathrm{X}$-ray-induced cataracts significantly. The amounts of non-protein SH groups, malondialdehyde and the $\mathrm{Na}^{+} / \mathrm{K}^{+}$ratio, in the lenses of rats post-treated with the drug were significantly maintained at normal levels even at 27 weeks after irradiation.

On the other hand, a single administration of $250 \mathrm{mg} / \mathrm{kg}$ of the compound, $30 \mathrm{~min}$ prior to irradiation had no effect on cataract progression induced by X-ray.

* 本報告は Curr. Eye Res., 11, 1099-1103（1992）に発表。

** 白内障研究所

*** 東京大学医学部 